\title{
Physico-chemical study of raw wastewater from Outat El Haj city, Morocco
}

\author{
Hassan Ech-Chafay ${ }^{1,}$, Mohamed Najy ${ }^{1}$, Fatima Zahra Talbi ${ }^{2}$, Abdellatif Elghazouany ${ }^{1}$, Mohamed Lachhab $^{1}$, and Driss \\ Belghyti $^{1}$ \\ ${ }^{1}$ Laboratory of Agro- physiology, Biotechnology, Environment, and Quality, Department of Biology, Ibn Tofail University, Faculty of \\ Science, Kenitra, Morocco \\ ${ }^{2}$ Laboratory of biochemistry, neurosciences, natural resources and the environment. Faculty of Sciences and Technologies, BP 577 , \\ Hassan First University, Settat, Morocco
}

\begin{abstract}
The climatic changes that the middle Moulouya region of Morocco has undergone in recent years, demographic growth and the development of urbanization have led to a significant decrease in the reserves of water that can be mobilized for domestic and agricultural uses. This deficit, between availability and need for water, will only increase with the increasing needs of the water consuming sectors. The main objective is to follow the physical-chemical evolution of raw wastewater in the city of Outat El Haj. Sampling took place over 12 months (2014-2015). The physical-chemical study of urban discharges from the city of Outat El Haj made it possible to define the pollution ratio per inhabitant between 17 and $21 \mathrm{mg} / \mathrm{hab}$.day with BOD5 concentration between $525 \mathrm{mg} / \mathrm{l}$ and $2125 \mathrm{mg} / \mathrm{l}$ and $\mathrm{pH}$ values near neutrality. The ratio COD/BOD5 is from 1.92 to 2.04 , shows the biodegradability of effluents, and may be treated by a biological system such as stabilization ponds as found nationwide. The values of the physical-chemical obtained are above the wastewater discharge standards recommended by the WHO and and the Moroccan standards. At the end of this research, it turned out that wastewater from the city of Outat El Haj is of lousy quality to very bad.
\end{abstract}

\section{Introduction}

In Morocco, the issue of water is one of the leading environmental problems, partly because of the health and economic consequences of water pollution and insufficient sanitation, and on the other hand, pressures on water resources due to the increase in water needs.

The town of Outat El Haj is one of the cities of Morocco in full urban expansion with an estimated daily volume of wastewater discharges going from 880 in 2005 to $1280 \mathrm{~m} 3 / \mathrm{J}$ in 2012 . These discharges will reach 6278 $\mathrm{m} 3 / \mathrm{J}$ in 12030 [1]. It is explained by the increase in the urban population, the increase in the supply and consumption of individual drinking water, and the significant use of water by the industrial sector. In this region, which is experiencing a water deficit, wastewater is discharged in its raw state at various points in Oued Moulouya. The discharge rate of raw sewage is intensifying with extremely rapid speed, thus constituting an important source of pollution [2], and the consequences are hellish on the quality of the rivers [3].

The present study firstly characterizes the urban discharges from the city of Outat El Haj, then conducts a physical-chemical analysis by determining specific major and global parameters, indicators of the state of pollution by water-worn out.

\section{Materials and Methods of study}

\subsection{Study area}

The city of Outat El Haj is located $250 \mathrm{~km}$ far from Fez and $130 \mathrm{~km}$ southwest from the city of Guercif on the National Route 15, which is also westbound by Missour and Midelt. The presence of the Middle Atlas chain in its northwestern limit, the high atlass to the south and the remoteness of the Mediterranean mitigate the creative marine influences of the rains and give the region a semiarid climate with long periods of drought. The latter has a direct impact on the water plan of the region [25].

The city of Missour is part of the watershed of Moulouya, which is the main river of the geographic region of North Eastern Morocco. It extends over an area of $10 \mathrm{Km} 2$. The average altitude is about $890 \mathrm{~m}$ (Fig. 1).

The wastewater sampling was carried out monthly, from November 2014 to October 2015 from two effluent collectors located near the Okba School, and the second in El Harcha district (Figure 1). The Samples of wastewater intended for physical-chemical analysis have been retained in accordance with the general guide for the conservation and handling of samples according to ISO $5667 / 3$ [4], and Guide of good practice [5].

\footnotetext{
*Corresponding author: hassanfes98@gmail.com
} 


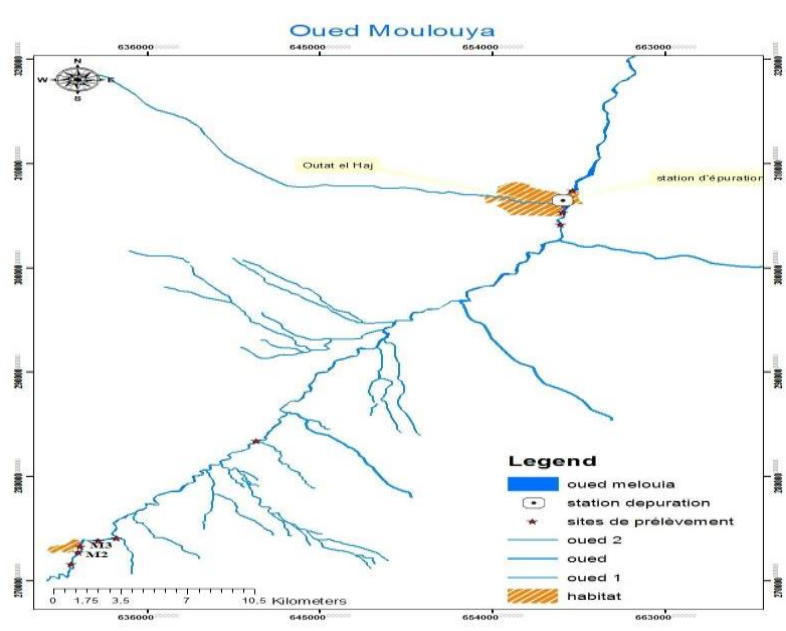

Fig. 1. Location of the study area and sampling sites

Some physicochemical parameters evolve during the transport and the conservation of samples from the sampling site to the laboratory. It is always better to take measurements on site. "In situ" measurements of temperature, $\mathrm{pH}$, electrical conductivity, dissolved oxygen and turbidity were performed using a mercury thermometer, a PH-2006 pH meter, a WTW conductivity meter (cond 315i), and an EUTCH oximeter, respectively. (cyberscan DO300) and a turbidimeter HACH 2100N.

The measures of all physical-chemical parameters are made within 48 hours of the levies, with standardised methods usually adopted for this type of analysis [6].

\section{Results and discussion}

\subsection{Evolution of chemical elements}

Table 1. Descriptive statistics of Physical-chemical constituents of wastewater

\begin{tabular}{|c|c|c|c|}
\hline Parameters & Min & Max & Moyen \\
\hline Temperature & 13,1 & 28,5 & 21,6 \\
\hline $\mathrm{pH}$ & 6,98 & 8,17 & 7,38 \\
\hline $\mathrm{CE}$ & 1916 & 4110 & 2626,5 \\
\hline Turbidity & 68,4 & 930,6 & 380 \\
\hline $\mathrm{O}_{2}$ & 0,04 & 0,53 & 0,23 \\
\hline $\mathrm{HCO}_{3}^{-}$ & 418,5 & 630 & 503,4 \\
\hline $\mathrm{Cl}^{-}$ & 276,9 & 594 & 363,4 \\
\hline $\mathrm{TSS}^{-}$ & 198 & 1976 & 949,1 \\
\hline $\mathrm{BOD}_{5}$ & 650 & 1120 & 851,7 \\
\hline $\mathrm{COD}^{-}$ & 1274 & 1960 & 1619,5 \\
\hline $\mathrm{NO}_{3}{ }^{-}$ & 4,06 & 53,4 & 26,06 \\
\hline $\mathrm{PO}_{4}{ }^{-}$ & 0,58 & 5,81 & 4,09 \\
\hline $\mathrm{OM}^{-}$ & 865 & 1306,66 & 1107,6 \\
\hline $\mathrm{NO}_{2}{ }^{-}$ & 0,22 & 0,96 & 0,63 \\
\hline $\mathrm{SO}_{4}{ }^{-}$ & 157,6 & 419,3 & 256,8 \\
\hline $\mathrm{TH}^{-}$ & 78 & 1130 & 714,9 \\
\hline & & & \\
\hline
\end{tabular}

The raw sewage temperature of the city of Outat El haj at an average of $21,6^{\circ} \mathrm{C}$.

Water temperatures are closely dependent on the air temperature. Since the samples were collected at the same time of the day, corresponding to the maximum period of sunshine, the temperature differences were not very extensive. The recorded wastewater temperature values are below $30^{\circ} \mathrm{C}$ which is considered as the limit value for direct discharge into the receiving environment [7]. Similarly, these values are below $35^{\circ} \mathrm{C}$, considered as an indicative (indicator) limit value for water intended for irrigation of Morocco [8].

These recorded temperature degrees are included in the range of the direct discharge limit values in the environment under question [7].

The $\mathrm{pH}$ values of the wastewater discharged by these releases range from 6.98 to 8.17 ; they are therefore relatively neutral. This result is similar to that found by [9] in Ouarzazate, by [10] in Oujda and by [11] in Kenitra. The PH measured values are acceptable according to Moroccan standards of quality of wastewater for irrigation [8]. As these values are between 6.5 and 8.5, they are considered to meet the limit values for direct discharges into the receiving environment [7]. The $\mathrm{pH}$ of wastewater in the city of Outat $\mathrm{El} \mathrm{Haj}$ is close to neutrality, with a slight tendency towards alkalization sometimes. This is attributed to the amount of groundwater (used for the production of drinking water) in bicarbonate ion [13], and the variation in temperature.

Analysis of the obtained results from dissolved oxygen shows that the minimum and maximum extreme values recorded are $0.04 \mathrm{mg} / 1$ and $0.53 \mathrm{mg} / 1$, with an average concentration of $0.23 \mathrm{mg} / 1$. This average value is lower than the one found at the level of wastewater in Marrakech (Morocco) [14].

A comparison of the dissolved oxygen values in the wastewater, analyzed with the surface water quality grid [8], makes it possible to deduce that this wastewater is of very poor quality. The significance of this parameter is very clear since the presence of dissolved oxygen conditions the reactions of aerobic degradation of the organic matter and more generally the biological balance of water environments.

The suspended solids represent all the mineral and organic particles contained in the wastewater. The Knowledge about the concentration of colloidal elements in wastewater is necessary for the evaluation of the impact of pollution on the aquatic environment. The amount of suspended matter varies between $169 \mathrm{mg} / \mathrm{l}$ and $5140 \mathrm{mg} / \mathrm{l}$, with an average of $1739,1 \mathrm{mg} / \mathrm{l}$.

The obtained results show that the values vary in the studied releases between a maximum of $198 \mathrm{mg} / \mathrm{l}$ and a minimum of $1976 \mathrm{mg} / \mathrm{l}$. The average of the two releases is $949,1 \mathrm{mg} / \mathrm{l}$.

The highest levels of measured TSS refer back to the month of March. This could be explained by a minimal consumption of water in this period of cold in the homes, which results in the discharge, in the sewers, of concentrated waste water, loaded in TSS. The values found in TSS are very high at $50 \mathrm{mg} / \mathrm{l}$ which is considered as wastewater standards for direct discharges [11]. 
The recorded values of BOD5 and COD are respectively between $525 \mathrm{mg} / \mathrm{l}$ of O2 and $2125 \mathrm{mg} / \mathrm{l}$ of $\mathrm{O} 2$, and between $1008 \mathrm{mg}$ of O2/1 and $4342 \mathrm{mg}$ of O2/1, with average values of $1063,7 \mathrm{mg} / \mathrm{l}$ of $\mathrm{O} 2$, and 2066,1 $\mathrm{mg} / \mathrm{l}$ of $\mathrm{O} 2$.

The COD concentration values vary between $1274 \mathrm{mg}$ / $\mathrm{L}$ as the minimum value recorded in March and the maximum value of $1960 \mathrm{mg} / \mathrm{L}$ recorded in August (Table 1). These values are lower than those found in Marrakech ( Morocco) (2983 mg / L) [14]. On the other hand, they are higher than those found in other Moroccan stations: Ouarzazate (571 mg / L) [15], Kenitra (501 mg / L) [16], and Souk Elarba of Gharb (235 mg / L) [17].

These concentrations are lower than the standards for the reuse of water intended for irrigation and the standards for direct discharge $(500 \mathrm{mg} / \mathrm{L})$ [11].

The BOD5 levels of raw wastewater in the city of Oujda range from $650 \mathrm{mg} / \mathrm{L}$ to $1120 \mathrm{mg} / \mathrm{L}$ with an average of $851.7 \mathrm{mg} / 1$ (Figure 8). This concentration is higher than that found in Marrakech (240 mg / L) [14], in Souk Elarba of Gharb (162 mg / L) [17] and in Kenitra $(335 \mathrm{mg} / \mathrm{L})$ [16]. These levels are much higher than the Moroccan direct discharge standards and those of water intended for irrigation [8].

The high BOD5 values could be explained by the abundance of organic matter, so $90 \%$ of the BOD5 values are above the usual Moroccan urban wastewater (MUW) ranges, and 10\% are included in the same ranges [18], [19] recorded for the companions of June(Figure ). The average value of BOD5 is greater than $100 \mathrm{mg}$ of O2/1 which is considered as the limit value for direct discharges [8]. This wastewater is classified as very poor, according to the quality standards of surface water [8].

The average value of the COD/BOD5 ratio is 1,9 corresponding to that of the wastewater with a ratio DCO / BOD5 of less than 3 [8]. Therefore, it can be concluded that even though urban wastewater has a high organic load, it is easily biodegradable. The review of this report highlights the biodegradability of wastewater mixed with municipal slaughterhouse discharges and discharges from the city's regional hospital to which biological treatment seems quite appropriate. These results are consistent with those reported by [20] and [21].

To characterize an industrial pollution, one often considers the ratio BOD5/COD, which gives very interesting indications on the origin of the waste waters pollution and its possibilities of treatment. For our study, this ratio is relatively average of the order of 0,51 . This is the general case for discharges loaded with organic matter. This organic load makes these wastewaters fairly unstable, that is to say they will evolve quickly to (into) forms "digested" with the risk of release of odors. Indeed, this type of wastewater is predominantly organic.

For raw wastewater from the city of Outat El Haj, the average ratio of BOD5 / COD is of the order of (0.52), which confirms that this wastewater is overloaded with organic matter. This obtained result is confirmed by the estimate of the oxidizable material, which is of the order of $1107,6 \mathrm{mg} / 1$ with a mean ratio of TSS /BOD5 with 1,63 , which allows us to deduce that the organic matter load in the city's wastewater is easily biodegradable according to Henze et al. [22].
The assessment of the degree of organic pollution locates the wastewater of the city in the average concentration range to be raised.

Wastewater taken from the city of Outat El Haj generates a significant pollutant load by spilling on the receiving environments such as Oued Moulouya, and especially during its stagnation when it can create a favorable environment for the proliferation of mosquitoes vectors of waterborne diseases, hence setting up a wastewater treatment plant for proper treatment in order to render the wastewater harmless for the receiving environment and for later reuse in irrigation is highly needed. At the end of the assessment of the degree of organic pollution, it can be seen that all the parameters studied (in particular with $\mathrm{BOD}_{5}, \mathrm{COD}$ and TSS) locate the wastewater analyzed in the medium-concentration slice to be raised [8].

The treatment of this wastewater is necessary to produce an effluent that meets the standards of direct and indirect discharges according to the Ministry of [8]. The City of Outat El Haj generates waste water that is suitable for biological treatment in terms of $\mathrm{COD}, \mathrm{BOD}_{5}$, and TSS. The following figures and table show the interpretation elements of the analysis (own values, the contributions of the parameters to the constitution of the principal components and matrix of the correlations): Table 2 allows a first topological approach of the various variables (16) and their grouping [23] on the first two principal components from their contributions. The first two factors account for nearly $50.81 \%$ of total inertia (Figure 3 ). The first axis F1 (27.76\% of inertia) mainly consists of a strong correlation with the parameters related to the organic load of water $\left(\mathrm{COD}, \mathrm{BOD}_{5}\right.$, alkalinity and suspended matter). Many parameters related to the mineralization (chlorides, salinity, sulphates and total hardness) show strong correlations with the second axis F2 (23.05\% of inertia) (figure 3$)$.

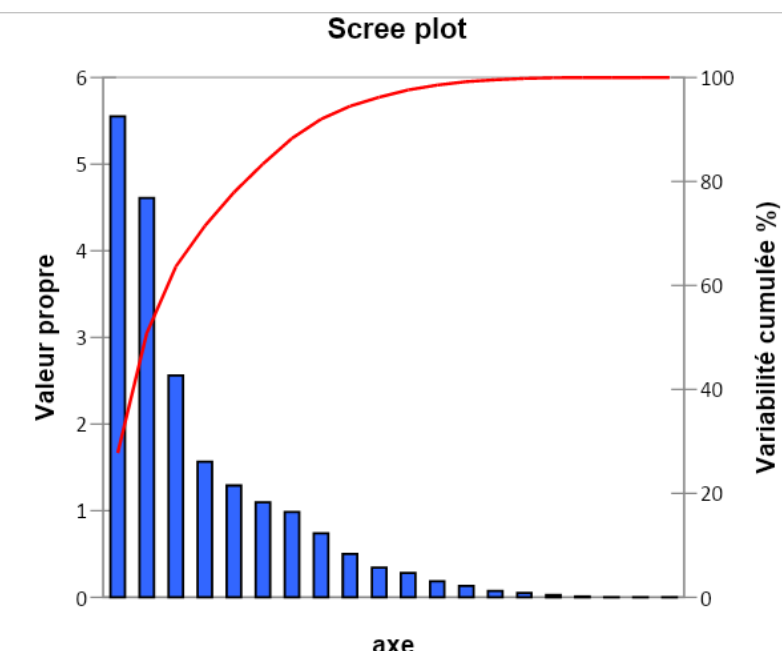

Fig. 2. Eigenvalue graphs

The Circle of correlations, which represents the projection of the coordinates of the variables in the plan of the first two components (Figure 3). This typology of the variables is accompanied by a typology of surveys that explains the phenomena, $50.81 \%$ of the information being 
held by the first two factors, only the representations in the plan F1 x F2 (Figure 3). Based on the maps of factorials F1 $\times$ F2 (Figure 4), the results of the ACP show that the majority of different months is positioned (on F1) depending on the degree of pollution of their waters. Thus, the most polluted the months of study (March, April, November, and December) are located in the negative side of F1, then that the months (June, July, September, and October) the least polluted by a report to the other lie on the positive side.

Table 2. Contributions of the parameters to the constitution of the principal components

\begin{tabular}{|c|c|c|}
\hline & F1 & F2 \\
\hline $\mathrm{T}$ & 11,314 & 0,226 \\
\hline $\mathrm{PH}$ & 9,586 & 0,003 \\
\hline $\mathrm{CE}$ & 10,767 & 1,073 \\
\hline Salt & 2,532 & 2,892 \\
\hline NTU & 1,149 & 1,437 \\
\hline $\mathrm{O} 2$ & 3,091 & 8,924 \\
\hline TSS & 4,637 & 1,074 \\
\hline $\mathrm{TH}$ & 5,531 & 0,787 \\
\hline $\mathrm{HCO} 3-$ & 0,685 & 4,658 \\
\hline $\mathrm{Cl}-$ & 6,449 & 0,557 \\
\hline COD & 7,499 & 9,662 \\
\hline BOD5 & 5,429 & 10,499 \\
\hline $\mathrm{MO}$ & 6,519 & 10,331 \\
\hline NO3- & 0,198 & 1,960 \\
\hline NO2- & 2,941 & 11,038 \\
\hline PO43- & 4,028 & 12,288 \\
\hline$P$ & 4,023 & 12,313 \\
\hline SO42- & 1,828 & 0,913 \\
\hline
\end{tabular}

Then, the projection of the individuals in the factorial plan F1 and F2 have helped to distinguish three different groups (Figure 4 and 5):

Group 1: it contains the months (November, January, February, and March), which has a water of inferior physical-chemical quality, characterized by a high concentration of organic matter.

Group 2: brings together the months of May, April, December, and June, which also have high levels of organic pollution indicator germ and nitrates, and sulfates.

Group 3: which has less polluted waters in parameters indicating organic pollution and in high dissolved oxygen concentration compared to the first month of groups 1 and 2.

An ascending hierarchical classification (AHC) has been performed on the physical-chemical data in order to complete the results of the PCA. The criterion used for $\mathrm{CAH}$ is that of maximizing the ratio of intergroup variance to intra-group variance. The frequent use makes the selection of an optimal number of partitions of $\mathrm{CAH}$ and dynamic clouds [24]. In our investigation, the classification was carried out on the average Values of the months calculated from the date of the different sampling stations (figure 4).

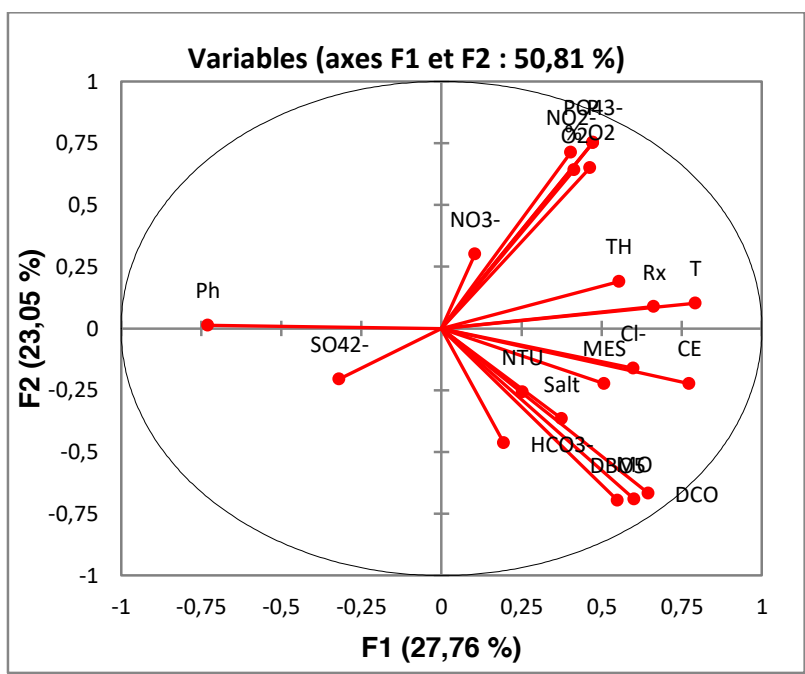

Fig. 3. Correlations circle of variable physical-chemical $F 1 \times F 2$

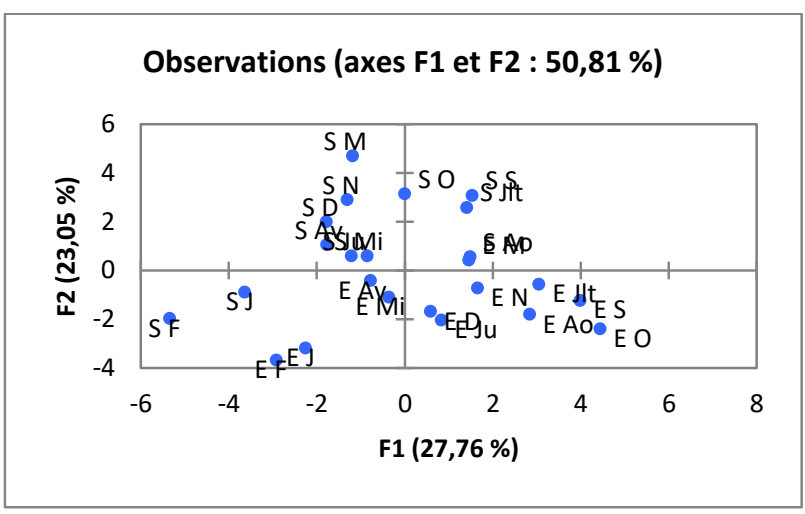

Fig. 4. Projected stations on the factorial plane F1 $\times$ F2

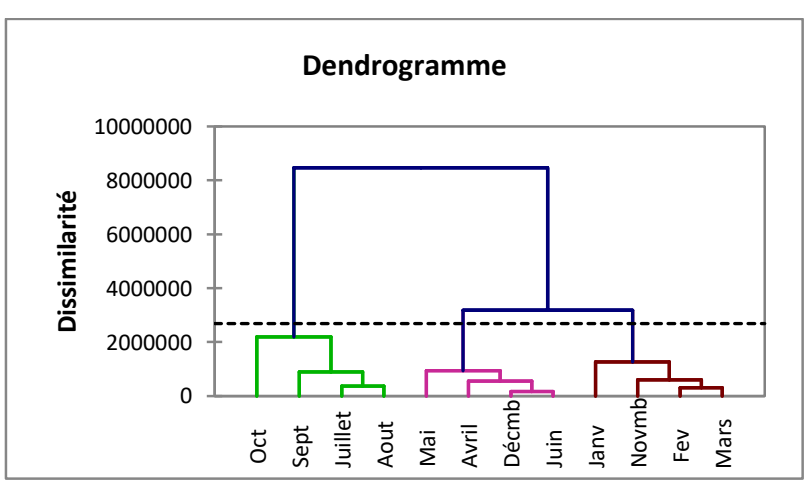

Fig. 5. Results of the ascending hierarchical classification of the 12 months of direct debit

This analysis made it possible to distinguish three groups of months, according to the anthropic influences to which they are subjected:

The months (November, January, February, and March) from the first $\mathrm{C} 1$ group characterized by a high concentration of organic matter, $\mathrm{COD}$ and $\mathrm{BOD}_{5}$.

The second group, C2 (May, April, December, and June) undergoing organic pollution characterized by intermediate detectors in nitrates, sulfates.

The last group C3 (October, September, July, and August) with little mineralization, all these stations having a high concentration of Nitrates, TH, Bicarbonates, orthophosphates and low content of TSS. 


\section{Conclusion}

This study represents the first experience of wastewater treatment in the city of Figuig. On the one hand, it enabled us to identify a set of physical-chemical characteristics that could guide the choice of the appropriate sanitation system, and on the other hand, it showed the positive and negative impacts on the receiving environment by that wastewater.

When choosing the center's wastewater treatment mode, it must be taken into account that the wastewater from the town of Outat El Haj contains a very high pollutant load of around $878.3 \mathrm{mg} / 1$ and is moderately biodegradable but do not present industrial pollution.

The organic pollution parameters (BOD5, COD, TSS) place these waters in the section, which exceeds the standards of indirect discharge. These results show the need for prior treatment of this wastewater to improve its quality according to the standards of indirect discharge into the natural environment. However, most of the parameters tend to improve during the flow; it is a natural purification.

Therefore, the wastewater studied, given its physicalchemical load, must not be reused directly. Treatment prior to any irrigation should be considered to improve their quality of the required standards and meet the expectations of consumers and public authorities in terms of protection of the environment and human health. With this in mind, an operating process by optional lagooning or, if necessary, by highefficiency lagooning could constitute an alternative to the reuse of these raw waters.

\section{References}

1. ONEP (2012): Rapport annuel d'exploitation du service assainissement liquide du centre d' Outat El Haj Mars: 2012. 17p

2. Chau K.W.\& Jiang Y.W. (2002). Water Res. 36 (8); 2029-2039.

3. Pesce S.F. \&Wunderlun D.A. (2000). Water Res. 34 (11); 2915-2926.

4. ISO 5667/3, Qualité de l'eau - échantillonnage Guide pour la conservation et la Manipulation des échantillons, 1994.

5. ONEP, Caractérisation quantitative et qualitative des eaux usées, Guide de bonne Pratique, Direction Laboratoire de la Qualité des Eaux, ONEP, Rabat, 1999.

6. RODIER J. L'analyse de l'eau naturelle, eaux résiduaires, eau de mer, 9 Edition Dunod, Paris, 1579p. (2009)

7. VLRDI: Valeurs limites des rejets directs et indirects du Maroc.

8. Ministère de l'Environnement du Maroc « Normes marocaines, Bulletin officiel du Maroc,» $\mathrm{N}^{\circ} 5062 \mathrm{du}$ 30 Ramadan, 1423. Rabat, 2002.

9. El Hamouri B. Mekrane M., Khallaayoune K., Merzouki M. \& El Maroufy M. 1993.
10. El Halouani H. 1995. Réutilisation des eaux usées en agriculture et leur impact sur l'environnement: cas de la ville d'Oujda. Thèse d'Etat, Univ. Mohammed Premier, Fac. Sci. Oujda.

11. Oulkheir S. 2002. Caractéristiques physicochimiques et micro-biologiques des eaux usées de la ville de Kénitra. Thèse de 3ème Cycle, Univ. Ibn Tofayl, Fac. Sci. Kénitra, 79 p.

12. Sonnenberg L.B. \& Holmes J.C. 1998. Physicochemical characteristics of dissolved organic matter in untreated and treated pulp and paper mill wastewaters. Vancouver, BC, April 1998.

13. TORRENS A., ALCALDE L., SALGOT M., CASANOVA P., QUERALT E., ELHACHEMI O., ELHALOUANI H. \& GONZALEZ C., (2010) : Sustainable water resources management in the Oasis of Figuig, Morocco.

14. Ouazzani N. (1998). Traitement extensif des eaux usées sous climat aride en vue d'une réutilisation en agriculture. Thèse d'Etat de l'Université Cadi Ayyad, Marrakech, $221 \mathrm{p}$.

15. El Hamouri B. et al. (1993), Performances de stabilisation de la station de Ouarzazate. Actes du séminaire : la recherche nationale dans le domaine Eau et Environnement, LPEE - Casa. (18-19)

16. EL GUAMRI Y. et al. (2006). Etude de la qualité physico-chimique des eaux usées brutes de la commune urbaine de Saknia, rejetées dans le lac Fouarat (Kénitra, Maroc)

17. Kbibch A. et al. (2011). ScienceLib. Editions Mersenne : Volume $N^{\circ} 110203$ Février

18. Edeline F. (1980): L'épuration biologique des eaux usées résiduaires, théorie et technologie. Edition CEBEDOC,

19. Celeux G., Diday E., Govaert G., Lechevallier Y., Ralambondrainy H. (1989). Clssification automatique des données, Dunod, Paris., 238p.

20. Gnagne T. et Brissaud. Sud Sciences \&Technologies, n¹1, Décembre 2003.

21. Zerhouni R. A, "Flore algale des eaux usées de la ville de Fès et étude de la capacité de certaines espèces à éliminer la charge azotée, phosphatée et quelques métaux lourds (Chrome et Cadmium)" Thèse de Doctorat, Faculté des Science, Dhar El Mahraz, Fès, Maroc, pp. 146, 2003.

22. Henze M., Harremoes P., Jansen J. L.C and Avrin E., "Wastewater treatment," 2nd Ed, springerverlag, Berlin, 1997.

23. Chessel D., Mercier P. (1993). Couplage de triplets statistiques et liaisons espèces environnement. In : Lebreton J. D. \& Ausselain B. (eds) Biométrie et Environnement, Paris Masson., 15-44.

24. Celeux G., Diday E., Govaert G., Lechevallier Y., Ralambondrainy H. (1989). Clssification automatique des données, Dunod, Paris., 238p.

25. Ech-chafay et al. (2018). International Journal of Research Science \& Management. 5, 1 (2018) 